\title{
Familial Dysalbuminemic Hyperthyroidism
}

National Cancer Institute

\section{Source}

National Cancer Institute. Familial Dysalbuminemic Hyperthyroidism. NCI Thesaurus.

Code C131813.

A genetic condition caused by a variant in the ALB gene, associated with increased affinity of albumin for thyroxine. 